\title{
Physical Education Professionals and their Role in Primary Care in Curitiba
}

\author{
O profissional de Educação Física e sua atuação na Atenção Primária à \\ Saúde de Curitiba
}

Diego Spinoza dos Santos¹, Marcelo Hagebock Guimarães', Letícia Carneiro', Lucélia Justino Borges²

\begin{abstract}
The aim of this study was to describe the inclusion of the Physical Education professor, relating historical aspects and outlining the role of these professionals in Primary Care in Curitiba, Brazil. Inclusion occurred in 2009 with the hiring of 29 professionals, 26 of whom were still employed in early 2016. Activities performed include exercise groups; individual care; clinical support; continuing education; health education; as well as participation in social control, by representing the profession at the Municipal Health Council of Curitiba and Teaching-Service integration via a Multidisciplinary Residency preceptorship. The historical background reveals advances, achievements and much more to accomplish, in a permanent and ongoing process.
\end{abstract}

\section{Keywords}

Motor Activity; Primary Health Care; Health Promotion; Physical Education

\section{Resumo}

O objetivo desse texto foi descrever a inserção do profissional de Educação Física, resgatando aspectos históricos e descrevendo a atuação desses profissionais na Atenção Primária à Saúde de Curitiba-PR. A inserção aconteceu em 2009, com a contratação de 29 profissionais, dos quais 26 permanecem em atuação até início de 2016. As ações desenvolvidas pautam-se em grupos de exercício físico; atendimento individual; apoio matricial; educação permanente; educação em saúde; além da participação no Controle Social, por meio da representação da classe no Conselho Municipal de Saúde de Curitiba e da aproximação Ensino-Serviço, com a preceptoria da Residência Multiprofissional. O percurso bistórico revela avanços, conquistas e um longo caminho a ser percorrido, que está em permanente construção.

\section{Palavras-chave}

Atividade motora; Atenção primária à saúde; Promoção da saúde; Educação Física.

\section{Introduction}

Physical inactivity is a major risk factor for mortality, making it important in national and international health policies. In Brazil, physical activity (PA) is a key component in public health policy ${ }^{1}$, and a priority of the National Health Promotion Policy ${ }^{2}$. Furthermore, PA is part of the Strategic Action Plan to Combat Chronic Noncommunicable Diseases ${ }^{3}$.

Thus, the inclusion of specialized PA professionals broadens the possibilities of health care provision and promotion. Curitiba was one of the first Brazilian cities to include Physical Education Professionals (PEPs) in health teams, in early 2009. With a population of 1,751,907 inhabitants ${ }^{4}$, the municipal health network is divided into ten sanitary districts, and

1 Physical Education Professional. Municipal Health Department of Curitiba 2 Federal University of Paraná. Physical Education Department
109 Health Units (HU) that provide Primary Health Care (PHC). In October 2015, the network had Family Health Strategy (ESF) coverage of $46.21 \%$ and 28 teams from the Family Health Support Center $(\mathrm{NASF})^{5}$. In this respect, given that studies on the inclusion of PEPs in primary care are recent, it is important to investigate the historical aspects and the possibility of socializing experiences, which could contribute to interaction with other professionals and increase knowledge of this topic.

Accordingly, the aim of this study was to describe the inclusion of PEPs, and investigate the historical aspects and role of these professionals in the PHC of Curitiba.

\section{History}

Although PEP have been able to work directly in the health sector for more than 15 years $^{6}$, the process of consolidating this field is still ongoing. 
In 2008, ministerial decree no. 154, which instituted the Family Health Support Center ${ }^{7}$, made it possible for municipal administrators to define its professional categories. One of the selection criteria was the presence of these professionals in the public service sector of Curitiba, which required a municipal decree to reorganize ESF regulations ${ }^{8}$. This document created the Primary Health Care Support Center (NAAPS), which established the professional categories and included the PEP, classified as a Sport and Leisure Advisor.

This nomenclature presented an obstacle to implementation of the policy, now reaffirmed by the enacted legislation, and the actual presence of these professionals in PHC, since they were assigned to the Municipal Department of Sport and Leisure (SMEL). After the internal selective process was concluded, 29 PEPs qualified for the ESF team in Curitiba, via NAAPS.

The professionals were advised of the situation of the municipal health network at a workshop aimed at providing experiences that qualified them for PHC. This meeting revealed a range of possible roles at NAAPS, with collective activities such as walking and stretching being the most prominent for the area of Physical Education (PE), .

Following the inclusion of these professionals, work was organized by following the guiding principles of this level of health care, based on legislation ${ }^{8}$ and the Basic Care Notebook (Caderno de Atenção Básica) no. $27^{9}$.

With the onset of PHC activities, based on National Health System (SUS) principles, PEPs began to more clearly understand the role of Social Control. Recognizing this tool showed the importance of mobilization and representation, difficult to achieve largely due to lack of knowledge regarding the process involved in a conference and the demands of representation in the National Health Council (CMS). At the first conference after PEPs joined the NAAPS, they were allotted five positions, thanks to the collaboration of the Regional Physical Education Council of the $9^{\text {th }}$ Region/Paraná (CREF9/PR), which selected the participants for this event.

This first experience involved learning about a hitherto poorly explored field, given that the debate on social participation was little discussed during academic formation ${ }^{10}$. At the end of this process, important for strengthening the inclusion of the profession in SUS, the PEPs were assigned one substitute position on the CMS (2009-2011), represented by CREF9/PR, which agreed to the suggestion of appointing a PEP.

Entering the PHC and developing the work process came under the auspices of the NAAPS. With the decree ${ }^{11}$, the centers began to operate under the NASF and underwent changes in their composition, following the National Basic Care Policy. Furthermore, to complement the PHC offered, support activities were reinforced, including: case discussion; individual or collective shared care; interconsultations and the creation of therapeutic projects. Thus, in addition to the Basic Care Notebook 27 guidelines, there was also an increase in the scope of activities performed by the PEPs.

Another important point was organizing the work process of NASF teams in Curitiba, which was defined by normative ruling ${ }^{12}$. This dictates that professionals employ people-oriented activities, thereby contributing to the enhanced ability of health care teams, incorporating new modes of care, aiding integration with other areas in the network and providing support in foreseen and unforeseen situations, not restricted to expected demand. To that end, interventions should be based on five important points: Clinical Support, Shared Care, Individual Care, Continuing Education, Educational Activities and Integration with Local and District Health Centers.

In this respect, a number of advances deserve attention, such as the creation 
in 2013 of the Physical Education Technical Council (CTEF), where professionals have the opportunity to discuss and prepare guidelines for the NASF. The aim of the CTEF is to consolidate PE as a strategic area in the production of health in neighboring territories and the municipality as a whole, seeking to compile indicators of concrete results of the work performed and help administrators with information on local practices.

Another regulatory framework that demonstrates this inclusion process and consolidation of PEPs in PHC was the creation of a specific role within the "Advisor in sport and leisure" position, differentiating the attributions of Municipal Health Department (SMS) professionals from their sport and leisure (SMEL) counterparts, via decree $e^{13-14}$.

It is important to highlight the initiatives to integrate teaching-service through a partnership with the Multiprofessional Residency in Elderly Health Care of the Caridade da Irmandade da Santa Casa de Misericórdia Hospital in Curitiba. The agreement, signed in July 2014, made it possible for residents to enter the area of physical education to directly develop their PHC skills, with a PEP preceptorship in the Municipal Health Department. To date, two professionals have completed their internship and two more residents initiated their activities in 2016.

Furthermore, the PEPs sought to broaden their participation in Social Control. After a lengthy and competitive process, they were awarded 1 seat and 1 substitute on the State Health Council of Paraná (2016-2019), making them political protagonists and policy makers on behalf of the profession, represented by CREF9/PR, which agreed with the suggestion to appoint 2 professionals to PHC.

\section{Performance of the professionals: activities developed}

The logic model (figure 1) shows that the activities performed go beyond the dynamization of physical exercise sessions. The functions of PHC professionals are well explored in the National Health System of Curitiba and reinforce the need to rethink the training models of future PEPs, since the many technological tools used at this level of health care have yet to be considered in undergraduate programs.

\begin{tabular}{|c|c|c|c|c|}
\hline Resources & Activities Developed & Products & Expected short-term results & Expected long-term results \\
\hline $\begin{array}{l}\text { Human Resources } \\
\text { (26 PEPs) } \\
\text { Physical Resources } \\
\text { (Health Units, } \\
\text { squares, parks, public } \\
\text { equipment and } \\
\text { community spaces) } \\
\text { Financial Resources } \\
\text { (Municipal Health } \\
\text { Fund) }\end{array}$ & $\begin{array}{l}\text { Physical exercise groups } \\
\text { (Supervised physical exercise } \\
\text { sessions). } \\
\text { Health Education } \\
\text { (Educational activities to encourage } \\
\text { the adoption of regular physical } \\
\text { activity as a health-promoting } \\
\text { behavior). } \\
\text { Permanent Health Education } \\
\text { (Technical-pedagogic support with } \\
\text { health unit professionals). } \\
\text { Individual treatment for health unit } \\
\text { users } \\
\text { (Appointments with a PEP and/or } \\
\text { shared with other PHC professionals). } \\
\text { Physical Education Technical Council } \\
\text { (Collegiate members discussion space } \\
\text { regarding the work process of PEPs in } \\
\text { the NASF). } \\
\text { Role in Social Control } \\
\text { (Periodic meetings with community } \\
\text { leaders debating the health situation } \\
\text { of territories in the Health Councils). }\end{array}$ & $\begin{array}{l}267 \text { exercises per week in } 97 \\
\text { health units } \\
\text { ( } 88.2 \% \text { PHC coverage in the } \\
\text { municipality). } \\
\text { Qualification in physical } \\
\text { exercise and PA in } \\
\text { the management of } \\
\text { Noncommunicable } \\
\text { contagious diseases (NCD) } \\
\text { (performed at } 97 \text { health } \\
\text { units through clinical } \\
\text { support). } \\
15 \text { Technical meetings on } \\
\text { the work process } \\
\text { (with 120 participations in } \\
\text { 2014-2015). } \\
\text { Representation in Health } \\
\text { Councils } \\
\text { (PEPs acting on local, } \\
\text { district, municipal and state } \\
\text { health councils). }\end{array}$ & $\begin{array}{l}\text { Promotion of healthier } \\
\text { lifestyles. } \\
\text { Provide access and advice } \\
\text { on PA. } \\
\text { Improve perception of } \\
\text { health and well-being. } \\
\text { Pain relief. } \\
\text { Improve quality of life. } \\
\text { Recognition and } \\
\text { appropriation of community } \\
\text { spaces as health promoting } \\
\text { environments. } \\
\text { Increased representativeness } \\
\text { of PE in Social Control. } \\
\text { PEP training for PHC. }\end{array}$ & $\begin{array}{l}\text { Maintain healthier lifestyles. } \\
\text { Increase in PA levels. } \\
\text { Reduce the number of } \\
\text { hospitalizations. } \\
\text { Improve chronic disease } \\
\text { management. } \\
\text { Improve municipal health } \\
\text { indicators. } \\
\text { Reduce risk factors for } \\
\text { the primary causes of } \\
\text { morbidities. } \\
\text { Improve quality of life. } \\
\text { Appropriation of } \\
\text { community spaces } \\
\text { as health promoting } \\
\text { environments. } \\
\text { Increase in social } \\
\text { participation. } \\
\text { Increase in the number of } \\
\text { PEPs in PHC. } \\
\text { Inclusion of PEPs in PHC } \\
\text { with specific training for } \\
\text { the health area. }\end{array}$ \\
\hline
\end{tabular}

FIGURE 1 - Logic model of the role of Physical Education professionals in Primary Health Care in Curitiba, Brazil. 


\section{Final considerations}

Investigating the history and measures that contribute to the process of consolidating PEPs in PHC of Curitiba reveals the political and training aspects as well as the construction of a new field in under expansion.

In the case of Curitiba, although 29 professionals were initially selected, the current team consists of 26 individuals ( 2 transferred to management and 1 returned to his original department). There is an urgent need for replacements/expansion, given the growing demand for the different activities developed in PHC. Another important aspect for all professionals the area is the need for a specific position within the municipal health system. This would make it possible to determine selection criteria based on the specific contents of Public Health, encouraging the specialization of PEPs in the national health system (SUS). Furthermore, it would involve reformulating curricula, highlighting the need for health-related disciplines beyond the biomedical standpoint.

Another point refers to the need to appropriate democratic arenas for the construction of health policies by Social Control, given the demand for inclusion of these professionals in SUS. This endeavor would emphasize the importance of PEPs in this area to municipal health administrators.

The historical background reveals advances, achievements and much more to accomplish, in a permanent and ongoing process.

\section{References}

1. Andrade DR. Políticas recentes de promoção da atividade física no setor da saúde no Brasil. Rev Corpoconsciência 2011; 15(2): 2-6.

2. Ministério da Saúde. Secretaria de Vigilância em Saúde. Secretaria de Atenção à Saúde. Política Nacional de Promoção da Saúde: PNPS: revisão da Portaria MS/GM n ${ }^{\circ}$ 687, de 30 de março de 2006. Brasília; 2015. Disponível em: https://goo.gl/itHQ7q [acesso em 08 jan 2016].

3. Ministério da Saúde. Plano de ações estratégicas para o enfrentamento das doenças crônicas não transmissíveis (DCNT) no Brasil, 2011-2022. Brasília; 2011. Disponível em: https://goo.gl/bO0ocv [acesso em 08 jan 2016].

4. Instituto Brasileiro de Geografia e Estatística. Sinopse do Censo Demográfico 2010. [acesso em 23 nov 2015]. Disponível em: http://www.censo2010.ibge.gov.br/sinopse/ index.php?dados $=68 u f=00$.

5. Ministério da Saúde. Departamento de Atenção Básica. Histórico de Cobertura da Saúde da Família. [acesso em 22 fev 2016]. Disponível em: http://dab.saude.gov.br/dab/ historico_cobertura_sf/historico_cobertura_sf_relatorio.php.

6. Conselho Nacional de Saúde. Resolução n ${ }^{\circ}$ 218, de 6 de março de 1997. Reconhece como profissional de saúde de nível superior os Profissionais de Educação Física. Diário Oficial da União 5 mai 1997. Disponível em: https://goo.gl/RG6vQH [acesso 08 jan 2016].

7. Ministério da Saúde. Gabinete do Ministro. Portaria no 154, de 24 de janeiro de 2008. Cria os Núcleos de Apoio à Saúde da Família - NASF. Diário Oficial da União 24 jan 2008. Disponível em: https://goo.gl/xhAa9T [acesso em 08 jan 2016].

8. Curitiba. Decreto ${ }^{\circ} 1.271$, de 27 de novembro de 2008. Dispõe sobre a regulamentação da Estratégia de Saúde da Família de Curitiba, na Secretaria Municipal da Saúde. Diário Oficial do Município 27 nov 2008. Disponível em: http://migre.me/veXdP [acesso em 08 jan 2016].

9. Ministério da Saúde. Secretaria de Atenção à Saúde. Departamento de Atenção Básica. Cadernos de Atenção Básica n. 27 - Diretrizes do NASF. Brasília; 2009. Disponível em https://goo.gl/paeVz [acesso em 01 fev 2016].

10. De Carvalho, YM; Ceccim, RB. Formação e educação em saúde: aprendizados com a saúde coletiva. Tratado da saúde coletiva. Rio de Janeiro: Fiocruz, 2006: 137-170. 
11. Curitiba. Decreto $n^{\circ} 560$, de 2 de abril de 2013. Dispõe sobre a regulamentação da Atenção Primária à Saúde na Secretaria Municipal da Saúde. Diário Oficial do Município 2 abr 2013. Disponível em: http://migre.me/veXly [acesso em 01 fev 2016].

12. Secretaria Municipal da Saúde (Curitiba). Instrução Normativa $n^{\circ} 1$, de 16 de janeiro de 2014. Estabelece diretrizes sobre o processo de trabalho dos profissionais dos Núcleos de Apoio à Saúde da Família (NASF) no município de Curitiba. Diário Oficial do Município 16 jan 2014. Disponível em: http://migre.me/veXob [acesso em 22 fev 2016].

13. Curitiba. Decreto $n^{\circ} 392$, de 2 de maio de 2014. Cria área de atuação, regula o procedimento de mudança de área para o cargo de Orientador em Esportes e Lazer e dá outras providências. Diário Oficial do Município 2 mai 2014. Disponível em: https:// goo.gl/9RgjYx [acesso em $22 \mathrm{fev} 2016$ ].

14. Curitiba. Decreto ${ }^{\circ} 505$, de 30 de maio de 2014. Altera o Decreto Municipal n. ${ }^{\circ} 1.119$, de 30 de novembro de 2004, e Decreto Municipal n. ${ }^{\circ}$ 704, de 27 de junho de 2006, na parte referente às atribuições, competências técnicas de ingresso, requisitos e demais características inerentes ao cargo de Orientador em Esporte e Lazer, da Administração Direta. Diário Oficial do Município 30 mai 2014. Disponível em: https://goo.gl/OPz7pF [acesso em 22 fev 2016].

Corresponding

Author

Diego Spinoza dos Santos

diegospinoza@hotmail.com
Rua Renato Polatti, 3539

Bairro Campo Comprido, CEP 81230-

170, Curitiba, PR, Brazil

Phone: 55419 9612-4374
Received

Revised

Approved
$02 / 04 / 2016$ $02 / 07 / 2016$ $04 / 07 / 2016$ 